\title{
Highly Enantioselective Addition of Allyltrimethylsilane to Aldehydes
}

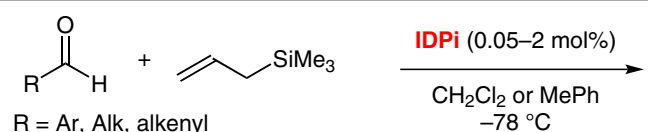

$$
\begin{aligned}
& \text { then aq } \mathrm{HCl}(1 \mathrm{M})
\end{aligned}
$$

\section{Selected examples:}<smiles>C=CCC(O)c1cc(O)c2ccccc2c1</smiles><smiles>C=CCC(O)/C=C/c1ccccc1</smiles><smiles>C=CCC(O)CCCC</smiles><smiles>C=CCC(O)CC(C)C</smiles>
er $=96: 4$

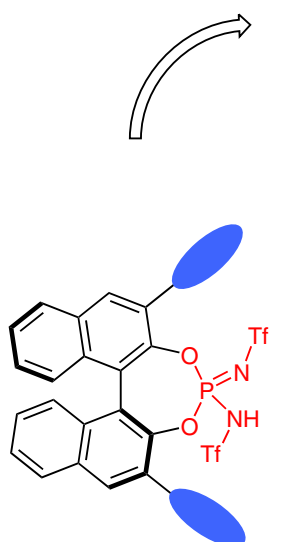

phosphoramidimidate

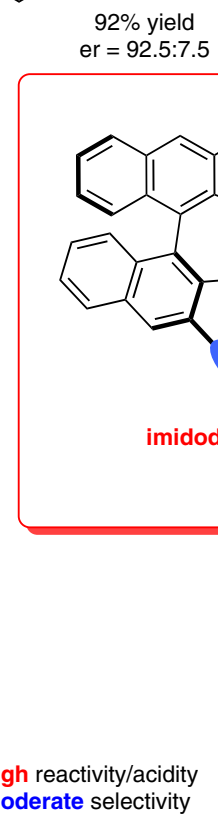
moderate selectivity

$$
\text { (1) }
$$

\section{Category}

Organo- and

Biocatalysis

\section{Key words}

silylium Lewis acids

Hosomi-Sakurai reaction

aldehydes

allyltrimethylsilane

imidodiphosphor-

imidates

asymmetric catalysis

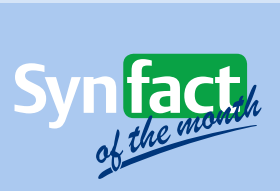

Significance: List and co-workers report the first general, highly enantioselective, organocatalytic addition of allyltrimethylsilane to aldehydes (the Hosomi-Sakurai reaction). This transformation is enabled by newly developed highly confined imidodiphosphorimidates IDPi. Various aromatic and aliphatic aldehydes are tolerated under the reaction conditions, affording the desired products in good to excellent yields and enantioselectivities (er $\leq$ 98:2).

SYNFACTS Contributors: Benjamin List, Grigory A. Shevchenko Synfacts 2016, 12(12), $1301 \quad$ Published online: 17.11.2016 DOI: 10.1055/s-0036-1589631; Reg-No.: B08016SF
Comment: The IDPi motif, which can be accessed by a single-flask synthesis from 3,3'disubstituted BINOL derivatives, is a combination of the recently developed highly confined imidodiphosphates (Nature 2012, 483, 315) and highly acidic BINOL-derived phosphoramidimidates (Synlett 2016, 27, 156). 